\title{
THE REFORMATION OF TURKISH COMMERCIAL LAW WITHIN THE PROCESS OF EUROPEAN UNION CANDIDACY
}

\author{
Mustafa Yasan*
}

\begin{abstract}
The relationship between Turkey and the European Union began in 1959 with Turkey's application for membership. This relationship has survived to this day and in this process negotiations for membership have been frozen. This process contributed directly to Turkish law. This contribution has become more significant, especially since 1999. Turkish Code of Commerce (TCC) entered into force in 2012, is recognized as a result of Turkey's EU process. By this Code, it is aimed to ensure harmonization between Turkish Commercial Law and EU legislation. For this reason, regulations in the sense of reform were included in the TCC. However, the Code has been amended for a total of eighteen times. Sixteen times after coming into force, and two times even before coming into force. More than three hundred articles have been directly affected by these changes. The principles foreseen in the Code have been abandoned because of adopting a populist approach. This situation is accepted as both a failure and disappointment for the TCC codification experience.
\end{abstract}

Key words: commercial law, process of European Union candidacy

* Associate Prof. Dr., Sakarya University Faculty of Law, mustafayasan@sakarya.edu.tr, ORCID: 0000-0003-0741-9720. 


\section{INTRODUCTION}

The dream of Turkey's membership of the European Union dates back to the 1950s. This dream causes a melancholic one-sided love story between Turkey and EU. Turkey has candidate country status for a long time and full membership negotiations are officially continuing despite any obstacles. On the other hand, the goal of full membership has been frozen because of the initiatives of the European Union institutions, and especially Greece and the Greek Cypriot Administration. However, from the perspective of membership, this pessimistic picture in the political situation is not in question about the modernization or harmonization of Turkish Law with the EU. Indeed, with the 1999 Helsinki Summit of the acquisition of the status of candidate country, Turkey undertook to harmonize its legal system with EU law. The political will saw this as an opportunity, started the codification efforts for renewal in all major codifications in private and public law. In this period, the TCC numbered $6102^{1}$ has an important place. Corporate governance, transparency, accountability, competitiveness, professionalism and compliance with technology are the pillars of the new TCC's philosophy. In the first version of the TCC published in the Official Gazette, this philosophy had been followed faithfully. On the other hand, the Code has been amended sixteen times after it entered into force and it had been amended two times even before it came into force. Due to the populist approach of political will, it has changed eighteen times in seven years. For this reason, the final version of the Code is far from the philosophy that inspired the codification efforts at the beginning. This codification experience is unfortunately considered as a failure and a huge disappointment despite all good faith efforts.

\section{A BRIEF HISTORY OF TURKEY AND EUROPEAN UNION RELATIONS}

The subject of this presentation is "Institutional Transformation of Turkish Commercial Law as a result of European Union Candidacy". In order to examine the topic, first of all, there should be a focus on the his-

1 Official Gazette, Date: 14.02.2011, No: 27846. 
torical development of the affairs between Turkey and the European Union. I underline the word "history" because it is really difficult to estimate an exact date when it will finish or whether it really ends in the future. Because, it has been almost 60 years since the first intention of being an EU member for Turkey. The first step of Turkey's relation with European Union was the Ankara Agreement which was signed with the European Economic Community in 1963. This agreement entered into force in 1964. However, before this Agreement, the first contact of Turkey to European Union was the application for membership. This application was made in 1959. Ankara Agreement formed the basic legal source which was also the framework of possible partnership status of Turkey. According to the Ankara Agreement, there were three stages for the integration of Turkey to the European Union². These stages were:

1) Preparational stage,

2) Transitional stage,

3) Final stage.

In the Agreement, it was also planned to complete the Customs Union with its all institutions at the end of the transitional stage.

The preparational stage was successfully completed by an Additional Protocol. The Additional Protocol was signed in 1970 and came into force in 1973. The provisions of the transitional stage and the obligations of both parties were determined in the Additional Protocol ${ }^{3}$.

At the end of the transitional stage, one of the most significant milestones, the Customs Union, which can be characterized as a revolution in Turkey-EU relations, entered into force in 1996. The level of integration between parties reached the advanced point by the Customs Union. After this point, the final stage was left: Turkey's full membership which was already determined in Ankara Agreement Article 28.

Another corner Stone of Turkey-EU relations was the Helsinki Summit. After this summit, a new period began in relations because Turkey got the "candidate country status" in the Helsinki Summit in 1999. It was so clear that the candidateship was determined for full membership. In other

2 Bozkurt, E., Köktaş, A., Avrupa Birliği Hukuku, 7. Baskı, Ankara, 2018, 400.

3 Bozkurt, Köktaş, 401. 
words, it was registered that the target at the end of this long journey was only full membership of Turkey ${ }^{4}$.

The Brussels Summit which was held in 2004 was another significant cornerstone because, in that summit, the EU Council took note that Turkey sufficiently fulfilled the political criteria and obligations. In addition to that, the EU Council decided to open accession of negotiations with Turkey. By this decision, the candidateship for full membership was reaffirmed.

\section{TURKEY'S EU CANDIDACY AND ITS EFFECTS ON TURKISH LAW SYSTEM IN GENERAL}

The date of the Helsinki Summit had a significant impact on the Turkish Legal System and Turkish Private Law in particular. The concept of harmonizing Turkish Private Law to the European Union Law, which was expected from European Union institutions, required reforms on the legislation of Turkey. I want to pay attention not to use the word "modernizing" instead of harmonizing. Because if there was a need for reforms to get the possible membership of Turkey, it was not because the Turkish Law system was just nonmodern, it was because of the lack of harmony between the EU and Turkish Legal systems. In order to provide harmony in private law legislation in both parties, from the beginning of the new Millennium up to now Turkish lawyers have been facing the efforts for codifications.

The first basic codification was the new Turkish Civil Code ${ }^{5}$ which was enacted in 2001 and came into force in 2002. After new Turkish Civil Code reform, it was turned for the other main private law codifications, such as the new Turkish Obligation $\operatorname{Code}^{6}$ and the new Code of Civil Procedure ${ }^{7}$ and finally the new Turkish Code of Commerce.

\footnotetext{
4 Bozkurt, Köktaş, 427.

5 Official Gazette, Date: 08.12.2001, No: 24607.

6 Official Gazette, Date: 04.02.2011, No: 27836.

7 Official Gazette, Date: 04.02.2011, No: 27836.
} 
The new Civil Procedure Code was enacted and came into force in 2011. However,the new Turkish Obligation Code and new Turkish Code of Commerce was enacted in this same period, the legislative body delayed the date of effectiveness for these Codes until July $1^{\text {st }}$, 2012. In short, the subject of this presentation (new Turkish Code of Commerce) can be evaluated as "new". However, the idea for a new Turkish Code of Commerce emerged for the first time soon after Turkey had got the status of candidateship for membership. That is why if we accept the year 1999 as the beginning of efforts for new commercial law codification, it is better to inform you about a brief history of this codification work before starting to explain the provisions which constitute this reform.

4. THE NEW TURKISH CODE OF COMMERCE AS A RESULT OF HARMONIZATION EFFORTS WITH THE EU LEGAL SYSTEM

\subsection{Codification Efforts in Turkish Commercial Law}

The new Turkish Code of Commerce is the $4^{\text {th }}$ commercial code of Turkey considering modern codes. The first Turkish Code of Commerce was codified in 1850 even before the Turkish Republic was founded in 1923. (Kanunname-iTicaret) That code was fully inspired by Code de Commerce (1807) of France. Since the Ottoman Empire had very close relations with France, it is easy to notice that there were significant reflections of Code de Commerce on Kanunname-iTicaret. The historians of law characterize this code as an only simple translation of Code de Commerce. After the Turkish Republic was founded in 1923 with the leadership of Mustafa Kemal Atatürk, Turkey and the Turkish Nation experienced a great number of reforms in many fields of social life. Of course, the legal system was an inseparable part of this social life.

The second commercial code of Turkey came into force because of the requirements for having a contemporary law system in 1926. That code was numbered 865 and was a part of new Turkish private law legislation which was based on secularism. That commercial code was repealed in 1957 by the third commercial law code of Turkey. That new code was 
numbered $6762^{\circ}$. Although that code had a date of entry into force as 1957, the review works of commission for the previous code had started in 1937 by the encouragement of Mustafa Kemal Atatürk. Turkish Code of Commerce numbered 6762 was influenced by Swiss Obligation Code. That is why that code's institutions had been regulated according to commercial enterprise concept. Comparing to previous code, 6762 Numbered Code was very close to perfect. However, because the developments occurred in commercial life around the world and new concepts and need to regulate complicated business world relations, the thought for codifying a completely new Code of Commerce was preferred instead of reviewing the recent Code. Another reason for choosing the possibility of a completely new regulation was the requirement for EU membership. Because of the lack of harmony between the Turkish Commercial Law system and the EU Commercial Law directives required the necessity for a completely new Code with new institutions and new understandings?

The start of the new Turkish Code of Commerce was given by the Minister of Justice in a meeting that was held in 2000. The commission was formed by academicians and practitioners. The head of the commission was Prof. Dr. UnalTekinalp who was the former head of Commercial Law Department of İstanbul University Faculty of Law. The commission had worked since the early months of 2000 and it took at least 5 years to finish the draft text of the code. In 2005 the draft text of the Code was published.

After the publication of the draft text of the Code, there were discussions in various academic platforms about it. However, it took just 9 months for the Government to sign the draft and let the Prime Ministry send the draft to the parliament which is the legislative body of Turkey (Türkiye Büyük Millet Meclisi: Grand National Assembly of Turkey). While evaluating the length of the 9 month period, it can be said that the Government could have waited for more before deciding that the draft sent to parliament was the final one. We have to admit that the discussions on the draft text of Code were not noticed by the Government as much as they should have been.

8 İmregün, O., Kara Ticaret Hukuku Dersleri, 11. Baskı, İstanbul, 1996,4.

9 Şener, O.H., Ticari İşletme Hukuku, Ankara, 2016,1, 2. 
The Draft of the New Turkish Code of Commerce had to wait for being discussed in the parliament for more than 5 years. During this period another commission for reviewing was appointed to update the draft according to discussions and comments done after the publication of the draft. After the second review commission finally finished the task, the final draft was enacted as the Turkish Code of Commerce Numbered 6102 by the legislative body on January $13^{\text {th }} 2011$. However, the date for entering into force was identified as of July $1^{\text {st }}$, 2012. It can be said that the reason for this delay was not related to academic purposes only, but also for the attempt of gaining time for the practitioners in commercial life. Before it entered into force, especially the dynamics of commercial life such as The Union of Chambers and Commodity Exchanges of Turkey had raised their voice because of the restrictions and sanctions regulated in the Code. Unfortunately, the Government approached in a populist way by taking notice of the critics of practitioners so it changed more than 90 articles in some way by updating Codes. Those updating codes were numbered 6273 and 6335. Thus, the New Turkish Code of Commerce had been changed two times even before it came into force. At last, on July 1 $1^{\text {st }}, 2012$ the new Turkish Code of Commerce came into force ${ }^{10}$. However, there were some specific articles of the new Code that would be applicable later than the date July the $1^{\text {st }}, 2012$. These regulations and the dates for entering into force can be listed like this:

- Regulations of Turkish Accounting Standards: January 1", 2013.

- The Provisions regulating the auditing of the capital companies (public limited companies, private limited companies): January $1^{\text {st }}, 2013$.

- The provisions regulating the liability of companies for activating their own web sites: July $1^{\text {st }}, 2013$.

- The provision regulating the necessity of the merchants for updating the commercial documents by adding the information of the merchant's registration number, trade name, registered office's and official web site's addresses: January 1 ${ }^{\text {st }}, 2014$.

10 Kendigelen, A., Türk Ticaret Kanunu Değişiklikler, Yenilikler ve İlk Tespitler, 3. Bask1, İstanbul, 2016, 2, 3. 


\subsection{The Analysis of the Turkish Code of Commerce's Systematic}

New Turkish Code of Commerce consists of 1535 Articles. The First 10 Articles are named as "Preliminary Provisions", and the last 15 Articles are categorized as "final provisions". The rest of the articles are divided into six main chapters. Each chapter is related to a specific commercial law branch.

The preliminary provisions include the articles which regulate the definitions of commercial provisions, commercial customs, commercial business, commercial cases, the evidences that can be used, limitation periods and commercial interests. On the other hand the final provisions include the articles which regulate the procedural norms of commercial companies' cases, the categorizing of enterprises and companies regarding the scales, electronic transactions in commercial life, obligation to set up a web page, the principles of corporate governance and prohibited transactions ${ }^{11}$.

The first chapter regulates commercial enterprise law (Articles between and including 11 and 123: 113 Articles).

The second chapter regulates commercial company law (Articles between and including 124-644: 521 Articles).

The third chapter regulates negotiable instruments law (Articles between and including 645-761: 117 Articles).

The fourth chapter regulates transportation law (Articles between and including 762-815: 54 Articles).

The fifth chapter regulates maritime law (Articles between and including 816-1262: 447 Articles).

The sixth chapter regulates insurance law (Articles between and including 1263-1520: 258 Articles).

Although the new Turkish Code of Commerce has 6 chapters related to 6 different commercial law branches, 6 commercial law branches are categorized into 2 groups by Turkish Commercial Law doctrine. The first group, which include commercial enterprise law, company law and negotiable instruments law, are called commercial law on overland. On the other hand, transportation law, maritime commerce law and insurance law

11 Ayhan, R., Çağlar, H., Özdamar, M., Ticari İşletme Hukuku, 12. Bası, Ankara, 2019,54; Çeker, M., Ticaret Hukuku, 6. Baskı, Adana, 2013, 13. 
constitute the second group which can't be called as a specific term. In this presentation, we will only focus on the specific provisions and institutions of the first three chapters. In other words, there will be explanations only about the branches of commercial law on overland, plus the beginning and final provisions.

\section{THE NEW TURKISH CODE OF COMMERCE'S ROLE ON THE REFORMATION OF COMMERCIAL LAW IN TURKEY}

In the preamble of the new Turkish Code of Commerce, it was made clear that the investment climate of the European Union was taken as the basis for the preparation of the Code. The ratio legis of the Code was to capture a commercial law system that is highly competitive in comparative law. In order to achieve this goal, corporate governance principles have been adopted by the legislator ${ }^{12}$. Necessary measures were taken for professional management especially for stock corporations. In principle, independent audit has been accepted for stock corporations. The principles of independent audit are determined as professionalism, impartiality, necessity, integrity and continuity. For accounting, commercial companies are subject to Turkish Accounting Standards which have adopted the principles of International Financial Reporting Standards. Corporate governance principles have become valid not only for companies traded on the stock exchange but also for closed type capital companies. Internal control, audit committee, internal audit, early detection and management of risk and executive private audit are specially regulated in capital companies and especially in public limited companies. It has become possible to include binding provisions for the resolution of legal disputes arising from company relations in company contracts. In order to fulfil certain works and transactions in accordance with TCC Article 366 and 375, the com-

12 Tekinalp, Ü., Tasarının Takdimi, Türk Ticaret Kanunu Tasarısı, Konferans, Ankara Üniversitesi Banka ve Ticaret Hukuku Araştırma Enstitüsü, 13-14 Mayıs 2005, Ankara, 2005,9; Türk, H.S., Tasarı Hakkında Genel Değerlendirme, Türk Ticaret Kanunu Tasarısı, Konferans, Ankara Üniversitesi Banka ve Ticaret Hukuku Araştırma Enstitüsü, 13-14 Mayis 2005, Ankara, 2005, 20. 
mittees and commissions with members of the management have been validated.

Transparency and auditability were aimed to dominate over the new company law system. In principle, all capital companies are subject to an independent audit and are required to set up a web page. With the principle of transparency, it is aimed to create disclosure policies regarding the public disclosure interest and to inform the shareholders regularly and to explain the possible effects of the decisions taken with financial statements and reports on business results. In order to realise the transparency, electronic transactions and information society services have been regulated. All companies subject to independent audit should set a website and disclose information such as financial reports, structural changes, court decisions and general assembly resolution on this site. Another principle dominating the TCC is the utilization of technological developments in commercial law. As a matter of fact, it was accepted to keep and store commercial books in electronic databases. In addition, it was also made possible to hold general assembly meetings online in public limited companies ${ }^{13}$.

\subsection{The Regulations as Reform in Commercial Enterprise Law}

A clear definition of the concept of commercial enterprise has been made for the first time in the TCC. This innovation is the result of the adoption of the modern system in the TCC and the adoption of commercial enterprise as the central concept ${ }^{14}$. The transfer of commercial enterprise has also been issued for the first time in the $\mathrm{TCC}^{15}$. In the period in which the former commercial code was valid, the transfer of commercial enterprise was issued only in the Turkish Code of Obligations $(\mathrm{TCO})^{16}$. The distinction

13 Tekinalp, 10; Türk, 25.

14 Sertoğlu, B., Ticari İşletme Devri, Ankara, 2019, 15, 16; Aydın, A., Ticari İşletme Kavramı, Unsurları ve Hukuki İşlemlere Konu Olması, Yeni Türk Ticaret Kanunu’nun Ticari İşletme Hukuku Alanında Getirdiği Yenilikler Sempozyumu, Kadir Has Üniversitesi Hukuk Fakültesi, 25, 26 Kasım 2011, İstanbul, 2012, 9.

15 Bozer, A., Göle, C., Ticari İşletme Hukuku, 5. Baskı, Ankara, 2018, 20; Çeker, 34; Şener, Ticari İşletme, 3; Sertoğlu, 16; Ayhan, Çağlar, Özdamar, 115.

16 Arıcı, M.F., Ticari İşletmenin Aktif ve Pasifi ile Devri, İstanbul, 2008, 25; Ayhan, Çağlar, Özdamar, 135; Sertoğlu, 28; Aydın, 18. 
between traders and non-traders has also been adopted in the new Code ${ }^{17}$. One consequence of this distinction is the requirement as to form which the warnings and notices between traders are subject to ${ }^{18}$. In the new TCC, these requirements as to form are no longer validity form requirements. They have been considered as the only condition required for proof $^{19}$.

The trader assistant types regulated in the TCC have been reduced to two. Mercantile brokers haven't been included in the new TCC ${ }^{20}$. Agencies and transport forwarders are trader assistants regulated in the TCC. The legislator regulated the agency by utilizing the EU acquis and directives. It has adopted the principle of regulating in favor of the agencies and it has securedthe agencies' rights and interests against trader clients ${ }^{21}$. Agencies' equalizing compensation requests have been regulated for the first time. Thus, for the first time, the demand regarded as a customer portfolio was clearly regulated by the TCC. Another regulation envisaged for the agency with the TCC is about the non-competition agreement ${ }^{22}$. The non-competition agreement is accepted as an institution that becomes effective after the agency relationship ends between the agency and its client traderand restricts the activities of the agency even after the relationship ends ${ }^{23}$.

Another prominent regulation in the commercial enterprise law by the new TCC is about the commercial registry. Commercial registry organization has been regulated with more institutional and professional priorities $^{24}$. The State and the relevant chamber of commerce and indus-

17 Yıldız, Ş., Gerçek Kişilerde Tacir Sıfatının Kazanılması, Yeni Türk Ticaret Kanunu'nun Ticari İşletme Hukuku Alanında Getirdiği Yenilikler Sempozyumu, Kadir Has Üniversitesi Hukuk Fakültesi, 25, 26 Kasım 2011, İstanbul, 2012, 21.

18 Şener, Ticari İşletme, 199.

19 Ayhan, Çağlar, Özdamar, 230; Çeker, 75.

20 Ayoğlu, T., Bağlı ve Bağımsız Tacir Yardımcıları, Yeni Türk Ticaret Kanunu’nun Ticari İşletme Hukuku Alanında Getirdiği Yenilikler Sempozyumu, Kadir Has Üniversitesi Hukuk Fakültesi, 25, 26 Kasım 2011, İstanbul, 2012, 49.

${ }_{21}$ Şener, Ticari İşletme, 349; Ayoğlu, 49; Bozer, Göle, Ticari İşletme, 117.

22 Kaya, A., Acentelik ile İlgili Yenilikler, Yeni Türk Ticaret Kanunu’nun Ticari İsletme Hukuku Alanında Getirdiği Yenilikler Sempozyumu, Kadir Has Üniversitesi Hukuk Fakültesi, 25, 26 Kasım 2011, İstanbul, 2012, 55.

23 Şener, Ticari İşletme, 388; Kaya, 65; Bozer, Göle, Ticari İşletme, 158.

24 Yanl, V., Ticaret Sicili, Yeni Türk Ticaret Kanunu’nun Ticari İşletme Hukuku Alanında Getirdiği Yenilikler Sempozyumu, Kadir Has Üniversitesi Hukuk Fakültesi, 25, 
try have been accepted as jointly and severally liable for damages arising from the maintenance of the commercial registry. This responsibility is not based on defects. In the commercial registry, the principle of trust in appearance has been adopted. Therefore, the content of the announcement is deemed to be valid when the published content of the announcement is different from the registered content ${ }^{25}$.

Commercial books have been further diversified by the new TCC. The board of directors' decision books, books of shares, general assembly negotiation and meeting books are also considered as commercial books. These new commercial books are those that are not related to the accounting of the business ${ }^{26}$.

Another issue regulated by the TCC and the commercial enterprise law is unfair competition. The unfair competition institution has also been regulated with a new approach in the new TCC. The legislation has been inspired by both EU law and Swiss law ${ }^{27}$. For an action to be deemed as unfair competition, the principle of honesty is adopted as the main criterion $^{28}$. For the first time, the fact that the general terms and standards are contrary to the honesty rule has been described as unfair competition ${ }^{29}$. Among the possible defendants as a result of unfair competition internet service providers have also been underlined and unfair competition cases against internet service providers have been regulated under a special title ${ }^{30}$.

The latest amendment to the TCC concerns commercial cases. According to Article 5A added to the TCC with the Code No. 7155, if the subject of a commercial case is compensation or receivable, it is necessary to apply

26 Kasım 2011, İstanbul, 2012, 89; Bilge, M.E., Ticaret Sicili, İstanbul, 1999, 9; İmregün, 49.

25 Çeker, 109; Yanlı, 95; Bilge, 25.

26 Altay, S.S., Ticari Kayıtlar ve Defterlerin Tutulmasına İlişkin Hukuki Esaslar ve İsbat Sorunu, Yeni Türk Ticaret Kanunu’nun Ticari İşletme Hukuku Alanında Getirdiği Yenilikler Sempozyumu, Kadir Has Üniversitesi Hukuk Fakültesi, 25, 26 Kasım 2011, İstanbul, 2012, 104, 105; Çeker, 170.

27 Yasaman, H., Haksız Rekabet, Yeni Türk Ticaret Kanunu’nun Ticari İşletme Hukuku Alanında Getirdiği Yenilikler Sempozyumu, Kadir Has Üniversitesi Hukuk Fakültesi, 25, 26 Kasım 2011, İstanbul, 2012, 33.

28 Yasaman, 37; Bozer, Göle, Ticari İşletme, 214.

29 Şener, Ticari İşletme, 605; Yasaman, 40.

30 Çeker, 150. 
to the mediation institution before the lawsuit is filed. This is a litigation requirement. The reason for predicting such a case is that the commercial disputes are resolved peacefully and the courts' workload is reduced.

\subsection{The Regulations as Reform in Company Law}

Company law is the branch of commercial law that has been the most amended by the new TCC. The legislator tried to create a new company law regime. In this regime, a world of companies that are transparent, auditable, in line with the legislation of the European Union, highly competitive and parallel to the technological developments arethe goal ${ }^{31}$.

One of the most important changes for the above-mentioned objectives is the adoption of independent audits for public and private limited companies. However, with Code No. 6335 and subsequent sub-regulations, unfortunately, significant returns have been made in the independent audit regime ${ }^{32}$. As a result of these returns, the independent audit principle has been valid for only one percent of the total public and private companies as of today. A similar provision is seen in obligations to set up a webpage. Accordingly, as a rule, all limited public and private limited companies are required to establish a web site, to make announcements on the web site and to include information about the company on the web site. However, by Code No. 6335 and the sub-regulations, the obligation to establish a web site was required for only the public and private limited companies subject to the independent audit. As a requirement of the corporate governance principle, the obligation to employ lawyers for public and private limited companies has been regulated. However, this innovation was completely abolished by Code No. 6335, too.

A change in the quality of the reform by the new TCC is about the ultra vires principle. The principle of ultra vires was abolished by TCC Article 125. Accordingly, commercial companies can qualify and assume debts outside of their business too. On the other hand, according to the scattered

31 Çeker, 215.

32 Şener, O.H., Limited Ortaklıklar, Ankara, 2017, 812; Yıldız, Ş., Limited Şirketler Hukuku, İstanbul, 2007, 268; Bahtiyar, M., Ortaklıklar Hukuku, 13. Bası, İstanbul, 2019, 248. 
provisions in the TCC, it is seen that the ultra vires principle hasn't been completely abolished and only has changed its shape. For example, it is obligatory to express field of operation in the trade names of stock corporationss and the authority to representin stock corporationsis limited to fields of operation ${ }^{33}$.

Both public and private companies have been allowed to be established with a single partner. As a reflection of European Union law, now it is possible to establish public and private limited companies with a single partner from the beginning. In accordance with the same provision, it is also possible that the number of partners of public and limited companies previously established with multiple partners to be single after the establishment ${ }^{34}$. The single partner can have all the powers of the general assembly, as long as the decisions are made in written form. In addition to public and private limited companies with a single partner, it has been made possible for the board of directors in public limited companies and managers in private limited companies to be composed of one member. It has also been possible that the members of the board of directors of public limited companies and the managers of private limited companies can be selected from among legal persons ${ }^{35}$.

In order to ensure corporate governance and transparency principles in the capital companies, the declaration of founders has been accepted as a requirement in the establishment of the companies. Unfortunately, in this provision, the legislator abolished the obligation of the statement of founders as first for public limited companies and later for private limited companies. In other words, the legislator has abandoned the requirements of transparency, corporate governance and auditability because of the populist approaches ${ }^{36}$.

The protection of capital is one of the priorities taken into consideration by the new TCC. In the first version of the Code, the prohibition on borrowing to the company was regulated with strict measures in both

33 Şener, Limited Ortaklıklar, 681; Yıldız, Limited Şirketler, 260; Bahtiyar, Ortakliklar, 234 .

${ }^{34}$ Şener, Limited Ortaklıklar, 23.

35 Çeker, 217.

36 Yildız, Limited Şirketler, 99. 
public and private limited companies. On the other hand, the effect and scope of this prohibition were narrowed by Code No. 6335. For this reason, it was caused to turn back from the expectations of the legislator in foreseeing the ban on borrowing to the company.

Another requirement of the principle of capital protection is the obligation to pay all of the cash capital share commitments before the establishment in the commercial companies. In the first version of the Code, all of the cash capital commitments had to be paid, and as a result of the changes made over time, it has become possible to establish the company without paying any cash capital commitments. In other words, a 180-degree turn was made in the system adopted for the fulfilment of cash capital commitments for private limited companies. Innovations related to the real capital elements for the establishment of the capital companies are also included in TCC. Accordingly, the establishment of companies will not take place legally without fulfilling the real capital commitments ${ }^{37}$. In addition, it is regulated as a prerequisite that in the case of public and private limited companies that if the real capital is committed, the right of foreclosure, precautionary measure and pledge on the assets are not allowed ${ }^{38}$.

Criminal and administrative sanctions have also been needed to achieve the objectives adopted by the TCC. Crimes and administrative sanctions were accepted in terms of deterrence.

\subsection{The Regulations as Reform in Negotiable Instruments Law}

Negotiable instruments law is regulated in the third chapter of the TCC. The amendments made in this chapter by TCC No. 6102 are very limited. In unjust enrichment in negotiable instruments institution, the statute of limitations is clearly determined as one year. In this way, the uncertainty on this issue was cleared ${ }^{39}$. The question marks regarding the application of unjust enrichment lawsuit on promissory notes have been eliminated. Apart from these, the amendments made on negotiable instruments by the TCC consist of the correction of translation errors and efforts

37 Şener, Limited Ortaklıklar, 107; Yıldız, Limited Şirketler, 104.

38 Bahtiyar, Ortaklıklar, 139.

39 Bahtiyar, M., Kıymetli Evrak Hukuku, 11. Bası, İstanbul, 2013, 105. 
to simplify the language even if it is inaccurate ${ }^{40}$. As in comparative law in the field of negotiable instruments law, the legislator preferred to adhere to the system of the Uniform Rules of Geneva and not to change this system ${ }^{41}$.

\section{THE EVALUATION OF TCC'S EFFECTS \\ ON THE TURKISH COMMERCIAL LAW SYSTEM}

There is no doubt that the process of European Union candidacy in Turkish law brings positive contributions. These contributions are obvious in the Turkish Code of Commerce Code, as well as in commercial law. The Turkish legislator has fulfilled the obligations of the European Union candidate status on its own and at least has done well. First of all, we must accept that this effort is a revolution. Considering the ignoring and discouraging approaches of the European Union institutions and European Union member states which plead the Turkey's possible membership as a threat, Turkey's effort for modernization and harmonization of legislation should be appreciated. However, the benefit of the process of candidate country status can be considered as contribution to the formation of an investment climate by harmonizing Turkish commercial law with EU legislation.

On the other hand, the TCC is considered as a failed codification movement. The reason for this is that the TCC has a completely different content than the original version published in the Official Gazette. The Code wasamended two times before it came into force and has been amended sixteen times after it came into force, in other words totally eighteen times in seven years. These changes caused the elimination of fundamental principles of the TCC and deviating from the targets of the legislator ${ }^{42}$. The legislator responded to the demands of the actors of commercial life with populist approaches. Therefore, the result can be summarized asfailure, disappointment and frustration.

40 Bozer, A., Göle, C., Kıymetli Evrak Hukuku, 8. Baskı, Ankara, 2018, 3.

41 Çeker, 453; Bozer, Göle, Kıymetli Evrak, 8.

42 Moroğlu, E., 6102 sayılı Türk Ticaret Kanunu, Değerlendirmeler ve Öneriler, 7. Baskı, İstanbul, 2012, 5; Kendigelen, 11. 


\section{CONCLUSION}

Turkish Commercial Law is bound to the continental European legal system both before and after the Republic of Turkey was founded. Because of this commitment, it is directly affected by developments in continental European law. This effect was evident in both commercial codes of 1926 and 1957. European Union candidacy process of Turkey which has been a long time is also forming the final chain of this effect. Currently Turkey's membership application process is frozen. In fact, Turkey-EU relations havereached abreaking point. Interventions from both sides have caused this negative and pessimistic situation in Turkey-EU relations. However, Turkey's EU membership motivation was evaluated as a new opportunity to make Turkey's legal system compliant again with the EU legislation. The Turkish legislator made good use of this opportunity. Since the beginning of the 2000s, all major codes have been renovated. Of these studies, the experiences of the Turkish Penal Code and the Turkish Code of Commerce failed. The reason for this failure was that the codes that came into force have been amended many times in a short period. TCC has been amended eighteen times in seven years. For this reason, good efforts with motivation for EU membership have been hampered by the populist approaches of political will. This situation has been described as a disappointment, frustration and failure in terms of commercial law codification experience.

\section{REFERENCES}

Altay, S.S., Ticari Kayıtlar ve Defterlerin Tutulmasına İlişskin Hukuki Esaslar ve İsbat Sorunu, Yeni Türk Ticaret Kanunu’nun Ticari İşletme Hukuku Alanında Getirdiği Yenilikler Sempozyumu, Kadir Has Üniversitesi Hukuk Fakültesi, 25, 26 Kasım 2011, İstanbul, 2012, 100-111.

Arıcı, M.F., 2008, Ticari İşletmenin Aktif ve Pasifi ile Devri, Vedat Kitapçlık, İstanbul.

Aydın, A., Ticari İşletme Kavramı, Unsurları ve Hukuki İşlemlere Konu Olması, Yeni Türk Ticaret Kanunu’nun Ticari İşletme Hukuku Alanında Getirdiği Yenilikler Sempozyumu, Kadir Has Üniversitesi Hukuk Fakültesi, 25, 26 Kasım 2011, İstanbul, 2012, 9-21. 
Ayhan, R., Çağlar, H., Özdamar, M., 2019, Ticari İşletme Hukuku, Yetkin Yay1nevi, 12. Bas1, Ankara.

Ayoğlu, T., Bağlı ve Bağımsız Tacir Yardımcıları, Yeni Türk Ticaret Kanunu’nun Ticari İşletme Hukuku Alanında Getirdiği Yenilikler Sempozyumu, Kadir Has Üniversitesi Hukuk Fakültesi, 25, 26 Kasım 2011, İstanbul, 2012, 46-53. Bahtiyar, M., 2013, Kıymetli Evrak Hukuku, Beta Yayınevi, 11. Bası, İstanbul. Bahtiyar, M., 2019, Ortaklıklar Hukuku, Beta Yayınevi, 13. Bası, İstanbul. Bilge, M.E., 1999, Ticaret Sicili, Beta Yayınevi, İstanbul.

Bozer, A., Göle, C., 2018, Kımetli Evrak Hukuku, Banka ve Ticaret Hukuku Araştırma Enstitüsü Yayınları, 8. Baskı, Ankara.

Bozer, A., Göle, C., 2018, Ticari İşletme Hukuku, Banka ve Ticaret Hukuku Araştırma Enstitüsü Yayınları, 5. Baskı, Ankara.

Bozkurt, E., Köktaş, A., 2018, Avrupa Birliği Hukuku, Legem Yayıncılık, 7. Bask1, Ankara.

Çeker, M., 2013, Ticaret Hukuku, Karahan Kitapevi, 6. Edition, Adana.

İmregün, O., 1996, Kara Ticaret Hukuku Dersleri, Filiz Kitapevi, 11. Baskı, İstanbul.

Kaya, A., Acentelik ile İlgili Yenilikler, Yeni Türk Ticaret Kanunu’nun Ticari İşletme Hukuku Alanında Getirdiği Yenilikler Sempozyumu, Kadir Has Üniversitesi Hukuk Fakültesi, 25, 26 Kasım 2011, İstanbul, 2012, 53-71.

Kendigelen, A., 2016, Türk Ticaret Kanunu Değişiklikler, Yenilikler ve İlk Tespitler, Oniki Levha Yayınları, 3. Baskı, İstanbul.

Moroğlu, E., 2012, 6102 sayılı Türk Ticaret Kanunu, Değerlendirmeler ve Öneriler, Oniki levha Yayınları, 7. Baskı, İstanbul.

Sertoğlu, B., 2019, Ticari İşletme Devri, Seçkin Yayınevi, Ankara.

Şener, O.H., 2016, Ticari İşletme Hukuku, Seçkin Yayınevi, Ankara.

Şener, O.H., 2017, Limited Ortaklıklar, Seçkin Yayınevi, Ankara.

Tekinalp, Ü., Tasarının Takdimi, Türk Ticaret Kanunu Tasarısı, Konferans, Ankara Üniversitesi Banka ve Ticaret Hukuku Araştırma Enstitüsü, 13-14 Mayıs 2005, Ankara, 2005, 7-17.

Türk, H.S., Tasarı Hakkında Genel Değerlendirme, Türk Ticaret Kanunu Tasarıs1, Konferans, Ankara Üniversitesi Banka ve Ticaret Hukuku Araştırma Enstitüsü, 13-14 Mayıs 2005, Ankara, 2005, 17-41.

Yanlı, V., Ticaret Sicili, Yeni Türk Ticaret Kanunu'nun Ticari İşletme Hukuku Alanında Getirdiği Yenilikler Sempozyumu, Kadir Has Üniversitesi Hukuk Fakültesi, 25, 26 Kasım 2011, İstanbul, 2012, 89-100.

Yasaman, H., Haksız Rekabet, Yeni Türk Ticaret Kanunu'nun Ticari İşletme Hukuku Alanında Getirdiği Yenilikler Sempozyumu, Kadir Has Üniversitesi Hukuk Fakültesi, 25, 26 Kasım 2011, İstanbul, 2012, 33-46. 
Yıldız, Ş., Gerçek Kişilerde Tacir Sıfatının Kazanılması, Yeni Türk Ticaret Kanunu'nun Ticari İşletme Hukuku Alanında Getirdiği Yenilikler Sempozyumu, Kadir Has Üniversitesi Hukuk Fakültesi, 25, 26 Kasım 2011, İstanbul, 2012, 21-33.

Yıldız, Ş., 2007, Limited Şirketler Hukuku, Arıkan Kitapevi, İstanbul. 
